Мирослав Павловић

Универзитет у Новом Саду

Филозофски факултет

Одсек за историју

mpavlovitch@yahoo.com
Оригиналан научни рад

примљено: 1. мај 2014

прихваћено: 1. октобар 2014

\title{
ОПШИРНИ (MUFASSAL) ДЕФТЕР ЗА СМЕДЕРЕВСКИ САНЏАК ИЗ 1741. ГОДИНЕ: СТРУКТУРАЛНА АНАЛИЗА *
}

Сажетак: Рад представља структуру османског опширног пописног дефтера (tapu tahrir defteri) за Смедеревски санџак из 1741. године. Након опсежне уводне студије о дефтерологији и посткласичној дефтерологији, извршено је поређење са осталим познатим студијама из исте научне области. Истакнуто је да је сам дефтер настао по класичном моделу, али се сугерише и да је порески систем морао кореспондирати са правилима посткласичне дефтерологије, односа земљишне површине и одређеног квалитета, као основним параметрима приликом одређивања пореског оптерећења, уз могућност фиктивности архивске грађе. На основу студије случаја, издвојен је порески образац, представљен оригинални документ, одговарајућа транслитерација и превод. Уз детаљна објашњења појединих пореских обавеза и указивање на њихову сагласност са османским пореским системом, указује се на разлике у приступима две свеске дефтера (под архивски сигнатурама TTD 17 и TTD 18), разне варијације и структуру и врсту додатних пореза.

Кључне речи: Османско царство, Смедеревски санџак, дефтерологија, tapu tahrir defteri, порески систем, öşür, resim.

Студије дефтерологије сврставају се међу најстарије научне области османистике. Заузимају место одмах уз проучавања мухиме (mühimme) дефтера, чијим су откривањима отпочињала модерна османистичка архивска истраживања. У Србији су покренута 1936. захваљујући Глиши Елезовићу и Фехиму Бајрактаревићу. ${ }^{1}$ У османистици је присутан термин дефтерологија који се односи на проучавање османских пописних књига - дефтера. Званичан назив ових докумената, царски дефтери (defter-1 hakani), често је у самим документима османске администрације и у савременој историографији замењиван називом

\footnotetext{
* Текст је настао као фазни резултат рада на пројекту Војвођански простор у контексту европске историје (број 177002) Министарства просвете, науке и технолошког развоја Републике Србије.

${ }^{1}$ Fehim Bajraktarević, Glavni Carigradski arhiv i ispisi iz njega, Prilozi za orijentalnu filologiju, No. VI-VII, 1958, 283-300; Gliša Elezović, Iz carigradskih turskih arhiva - Mühimme defteri, Beograd 1951; Ljiljana Čolić, Orijentalističko delo Gliše Elezovića, Beograd-Priština 1996.
} 
пописни дефтери (tahrir defterleri), тј. поседовно-пописни дефтери (tapu tahrir defterleri). Тек у периоду после Другог светског рата проучавање и систематско публиковање дефтера постаје пракса, како историографије некадашњих периферних земаља Османског царства, попут мађарске и југословенске, тако и заговорника друштвене историје у духу школе анала, предвођених Омером Лутфијем Барканом и Халилом Иналџиком. Захваљујући Нежату Гојунћу, који се и сам истакао у овој области, млађа генерација османиста током седамдесетих година XX века обележила је најзначајније доба дефтерологије. Несумњиво до данас највећи дефтеролог Хит Лаури налази се на њеном челу. Махиел Кил, Клаус Крајзер, Ханс Георг Мајер, Џон Александер, нешто мање Суреја Фароки и Илбер Ортајли представници су те генерације. Готово да нема османисте који је током своје каријере заобишао ову научну област. Дефтеролошке студије карактерише почетни ентузијазам, затим нагло разочарење и готово потпуно напуштање рада са дефтерима. Лауријево искуство је парадигма без преседана у том смислу. ${ }^{2}$ Постојеће студије оријентисане су на класични период османске историје, што је у складу са бројношћу самих извора. У новије време отпочело је проучавање дефтера из транзиционог доба (XVII-XVIII век), које Елијас Коловос симболично назива посткласичном дефтерологијом. ${ }^{3}$ Иако су настали углавном након повратка одређене територије под османску власт, важно је истаћи да се новоорганизовани управни систем заснива на пређашњем уређењу под Османлијама, уместо затеченом стању стране управе. Карактерише их унеколико измењен метод обрачуна пореских дажбина. Основа дефтера постаје земљишна територија која се додељује једном домаћинству (baştine). Овај метод, који је доприносио илтизам систему, није својствен функцији и структури саме дефтерологије, која се управо током транзиционог периода напушта као бирократска метода. Процес фискалне трансформације условио је дислокацију пореских оптерећења и битне измене пореског система. Посткласични дефтери зато симболизују усамљене случајеве старе праксе и као такви не омогућавају компаративне студије. Пракса израде дефтера окончана је последњим пописима за читаво царство током султана Мурата III (1574-1595). У познатим случајевима дефтери за Крит и Егејска острва из 1670/71, Једрене 1669/1670. и Мореју 1716. садрже податке о приходима одређеног домаћинства са тачно спецификоване земљишне површине. ${ }^{4}$ Дефтер за Смедеревски санџак из 1741. не садржи потпуне податке својствене посткласичној дефтерологији,

\footnotetext{
${ }^{2}$ Heath Lowry Jr, Studies in Defterology. Ottoman Society in the Fifteenth and Sixteenth Centuries, Istanbul $1992,7$.

${ }^{3}$ Elias Kolovos, Beyond 'Classical' Ottoman Defterology: A Preliminary Assessment of the Tahrir Registers of 1670/71 Concerning Crete and the Aegean Islands, u: The Ottoman Empire, The Balkans, The Greek Lands: Toward a Social and Economic History. Studies in Honor of John C. Alexander (E. Kolovos, Ph. Kotzageorgis, S. Laiou, M. Sariyyanis, Eds.), Istanbul 2007, 201-235.

${ }^{4}$ Stefka Parveva, Villages, Peasants and Landholdings in the Edirne Region in the Second Half of the $17^{\text {th }}$ Century, u: Regions, Borders, Societies, Identities in Central and Southeast Europe, $17^{\text {th }}-21^{\text {th }}$ Centuries. Bulgarian-Hungarian History Conference Sofia 16-17 May 2012 (Eds. Penka Peykovska, Gabor Demeter), Sofia-Budapest 2013, 15-35; Stefka Parveva, Agrarian Land and Harvest in South-West Peloponnese in the Early $18^{\text {th }}$ Century, Etudes Balkaniques, 2003, Issue No. 1, 2003, 83-113; Fariba Zarinebaf, John Bennet, Jack Davis, A Historical and Economic Geography of the Ottoman Greece. The Southwestern Morea in the $18^{\text {th }}$ Century, Athens 2005.
} 
али је примењени метод сличан. Компарирањем уписаних бројчаних вредности, не могу се добити егзактни научно верификовани подаци, јер се висине пореског оптерећења по домаћинству превише међусобно разликују, показујући варијације на основу којих није могуће извршити систематизацију. Тиме се умногоме губи поузданост архивске грађе и отвара питање њене кредибилности. С друге стране, уколико се претпостави да дефтер исказује социјално раслојавање примећено у осталим случајевима, основа за попис морала је бити земљишна територија и сам квалитет земље, чиме је и пореско оптерећење зависило од процењеног приноса. С обзиром на то да није могуће утврдити величине земљишних поседа, сваки будући рад са дефтерима остаће проблематичан.

Процедура за попис Смедеревског санџака отпочела је у последњој декади јануара 1740. када је београдском мухафизу Али-паши упућен ферман са обавештењем о именовању пописивача. У питању су тројица писара Царске дефтерхане Абдурахман Ситки, Али Али и Мехмед Вахдети. Попис је истовремено обухватио и Видински санџак и Босански ејалет. ${ }^{5}$ На основу Увода из самог дефтера јасно је да је до средине јуна 1741. целокупан посао обављен и да је извршен коначан препис дефтера, после чега је уследила расподела тимара. Обновљеном Смедеревском санџаку придодате су четири нахије (Ужице, Пожега, Осад и Ниш) које су му и раније припадале и у којима с обзиром на то да нису потпале под страну власт није спроведен попис. Може се претпоставити да он није био нужан, јер је постојећи тимарски систем функционисао. Нахија Шабац (Boğurdelen) је обухваћена пописом ејалета Босна, којем је и припадала, а Смедереву ће бити прикључена касније.

Дефтер за Смедеревски санџак подељен је у две свеске које се воде под архивским сигнатурама TTD 17 и TTD 18. ${ }^{6}$ Прва обухвата нахије Ресаву (Resava), Пожаревац (Pojarofçe), Хомоље (Omol), Пореч (Poreç), Млаву (Milava), Звижд (Ijvijd) и Храм (Hram). Друга је нешто већа: Београд (Belgrad), Авала (Havala), Железник (Jeleznik), Браничево (Bran), Голубара (Golubara), Ломница (Lomniçe), Левач (Lefçe), Лепеница (Lepeniçe), Ваљево (Valyevo) и Морава-Рудник (Morava-1 Rudnik). Први дефтер је и по структури пореских оптерећења једноставнији и у приличној мери унификован, док је другим обухваћена територија великих, централних нахија са најгушћом насељеношћу и прилично сложеном структуром насеља. Порески образац је услед тога јединствен за свако насеље у првом дефтеру, док су другом осим тих основних пореских ставки често придодате још неке. Обновљени Смедеревски санџак имао је седиште у Београду и његов формални назив никада није био промењен. У свим документима османске провенијенције у употреби је искључиво формални назив провинције уз варијације саме интитулације. Заповести се најчешће упућују београдском мухафизу, односно мутасарифу Смедеревског санџака и београдском мухафизу (Semendire Sancağı mutasarıfı ve Belgrad muhafizi).

\footnotetext{
${ }_{5}^{5}$ Радмила Тричковић, Катастарски попис Крајине и Кључа из 1741. године, Мешовита грађа, књ. 2, 1973, 243-244.

${ }^{6}$ Tapu ve Kadastro Genel Müdürlüğü, Tapu Arşiv Dairesi Başkanlığı, Tapu Tahrir Defterler (даље: TKGM. TADB. TTD.), No. 0017; No. 0018. Треба напоменути да су у досадашњој литератури у употреби биле старије сигнатуре TTD 422 и TTD 423.
} 
Сама промена седишта санџака условила је интитулацију његовог санџакбега. Управо због промена статуса није постојала нахија Смедерево, која је задржала статус казе, временом постепено у функционалном смислу изгубљен. Традиционални поредак се огледа и код нахија Браничево, Железник (9 насеља) и Голубара (11 насеља). Иако је првобитно због величине и значаја области Браничева у ранијој историји попис за ову област вршен посебно, до средине XVIII века она је сведена на свега једанаест насеља и један манастир. ${ }^{7}$ Насупрот томе, Левач са 201 насељеним местом и Лепеница са 299 далеко су најбројније нахије. Укупно у 17 од 21 нахије обухваћене пописом забележено је 1.398 топонима. За свега 570 (40,8\%) насељених места постоје унета имена носилаца домаћинства. Број домаћинстава у овим насељима је 6.316. Код преосталих 828 насеља $(59,2 \%)$ прикупљање пореза вршено је одсеком, а у сам дефтер уношена једино коначна сума. Неретко је уз изостављање броја становника и њихових имена, као и испенџе, ипак уписивана врста осталих елементарих пореских оптерећења у складу са поменутим обрасцем. За разлику од претходног дефтера TTD 166 (насталог између 1574. и 1595) нису посебно бележена имена удовица (bive) и неожењених (mücerred). ${ }^{8}$ Удовице на челу домаћинстава су нотиране по редовној процедури, као и мушкарци носиоци домаћинстава. Битно је нагласити да је готово немогуће установити популационе прилике на основу података које пружа дефтер, те би у том смислу сваке претпоставке, како истиче и Лаури, представљале практиковање алхемије.

Сам дефтер из 1741. не садржи на свом почетку, како је то уобичајено, кануннаму нити канун. Тиме се поставља питање функционисања правног система и што је најбитније размер односа коришћених мерних јединица. Претпоставка од које се мора кренути јесте Канун за Смедеревску ливу из TTD 166 који је домаћој јавности познат захваљујући Душанки Бојанић Лукач. ${ }^{9}$ С обзиром на то да није остављен ни простор за уписивање кануна, а да је порески образац готово идентичан са старим дефтером, логично се намеће закључак да је и нови дефтер настао по правном систему који је у Смедеревском санџаку важио непосредно пре хабзбуршког освајања. Томе у прилог иде, како је већ истакнуто, и сама управна структура. На основу пређашњег могло би се закључити да је лукно имало 7 кејла, кејл је садржавао 20 ока. Медра шире је имала 10 пинти, односно 44 оке. ${ }^{10}$ Дељењем новчаних сума житарица изражених у акчама са еквивалентом у кејлима добија се референтна вредност 7, што се може тумачити као посредна потврда исправности рачунања вредности лукна од 7 кејла. Код шире је та референтна вредност 5 . Испенџа је прикупљана у вредности од 25 акчи по домаћинству, што се може сматрати веома ниском сумом, јер је истоветан износ задржан још од XVI века, а у

\footnotetext{
${ }^{7}$ Momčilo Stojaković, Braničevski tefter, Beograd 1987; TKGM. TADB. TTD No. 18, str. 101-114.

${ }^{8}$ TKGM. TADB. TTD No. 166.

${ }^{9}$ Dušanka Bojanić, Turski zakoni i zakonski spomenici iz XV i XVI veka za Smederevsku, Kruševačku i Vidinsku oblast, Beograd 1974, 82-89.

${ }^{10}$ Душанка Бојанић кејл (keyl) преводи као мерицу, док Радмила Тричковић употребљава термине кила и мерица. Овде је задржан оригиналан османски термин. Како је вредност једне оке 1,28 кг, лако је могуће постојеће османске мерне јединице претворити у килограме. D. Bojanić, Turski zakoni i zakonski spomenici iz XV i XVI veka, 86; Р. Тричковић, Катастарски попис Крајине и Кључа из 1741. године, 246-247.
} 
Браничеву још од пописа из $1467 .^{11}$

Османски порески систем није подразумевао унификованост на територији Царства, већ су примењивани прописи из канунама за сваки санџак понаособ. Услед тога порески модел и начин груписања одређених пореза представљају посебне случајеве, те им се мора приступити као студији случаја. Ипак, бирократски апарат није могао креирати нови систем, већ се он заснивао на искуствима шеријатских пореза и оних прописаних кануном. Џизја (сіzye), односно главарина, узимана је од одраслих пунолетних мушкараца немуслимана способних за рад. У посткласичном периоду прикупљана је путем посебних дефтера џизје, те није уношена у пописне дефтере. $^{12}$ Под ушуром (öşür) се подразумева десетина од пољопривредних производа. Од врсте производа зависила је и висина пореског оптерећења, која је прописивана у кануннами и кретала се у распону од $1 / 7$ или 1/8 до 5/10. Сам ушур је проистекао из харача (harac), на основу правних тумачења шејхул-ислама Ебусуудефендије. ${ }^{13}$ Опорезивање земље (harac-1 müvazzaf) вршено је кроз неколико различитих пореза. Чифт ресми (çift resmi) плаћали су муслимани по глави породице, односно домаћинства, док су хришћани плаћали испенџу (ispence). Посебан порез на земљу (resm-i dönüm; resm-i zemin) плаћан је у зависности од квалитета и величине обрадиве површине. У ову групу намета спадали су и порез на удају (resm-i arus), стоку (resm-i ağnam; adet-i ağnam), одбеглу стоку (resm-i kaçkun), клање свиња (resm-i bojik), млинове (resm-i asiyab; asyab), удовице (resm-i bive), неожењене (resm-i mücerred), порез за зимовник оних који долазе са стране (resm-i duhan), напасање њихове стоке (resm-i otluk) и порез који су одбегли дужни надокнадити спахији (resm-i çiftbozan). Треба споменути и порез на казнене и криминалне преступе (resm-i cürm ü cinayet) који је ишао држави или спахији на сербест поседима и на пренос поседа са једног лица на друго (resm-i tapu). Често се последњи намет налазио у оквиру бадихаве ${ }^{14}$ као што је случај и са казном за штету на усевима (adet-i deştbani, resm-i destbani). Група пореза на производе са земље (harac-1 mukasem), односно ушур, била је једнако разнолика. Овде ће бити наведени само основни производи од којих се прикупљао ушур: виноград (bağ), воћњак (bağçe, fevakih), ливада (giyah, çayır), сок од грожђа (şira, şıra), башта (bahçe), поврће

\footnotetext{
${ }^{11}$ Вредност испенџе од 25 акчи среће се како у Румелији у XVI веку тако и у Анадолији. TKGM. TADB. TTD No. 166; Nejat Göyünç, XVI. Yüzyılda Mardin Sancağl, İstanbul 1969, 138; M. Stojaković, Braničevski tefter, passim.

12 О дефтерима џизје вид.: Hamid Hadžibegić, Džizja ili harač, Prilozi za orijentalnu filologiju, No. V, 1954-55, 43-102; M. Kiel, Remarks on the Administration of the Poll Tax (cizye) in the Ottoman Balkans and Value of the Poll Tax Registers (cizye defterleri) for Demographic Research, Etudes Balkaniques, No. 4, 1990, 70-103; Oktay Özel, Osmanlı Demografi Tarihi Açısından Avarız ve Cizye Defteri u Osmanlı Devleti'nde Bilgi ve İstatistik (Ed. Halil İnalcık, Şevket Pamuk), Ankara 2001, 35-50; Süleyman Demirci, The Functioning of Ottoman Avariz Taxation: An Aspect of the Relationship Between Centre and Periphery. A Case Study of the Province of Karaman, 1621-1700, Istanbul 2009, 14-41.

${ }_{13}$ Харач је порез који се узимао за земљу коју освоје муслимани од локалног становништва (araz-1 haraciyye). Један део пореза је узиман на земљу (harac-1 müvazzaf) а други део на производе са земље (harac-1 mukasem), из кога је настао ушур.

${ }^{14}$ Бадихава (bad-1 heva) у основном значењу подразумева закон одређене провинције на основу кога се кажњавају преступници који нису пореклом са те територије. Под овим пореским оптерећењем прикупљано је од XVI века неколико обједињених пореских ставки.
} 
(bostan, büstan), кошнице (kovan, küvvare, kivare), риба (ăg, balık), дрво (odun), огревно дрво (hime), жир (bellut). Што се тиче житарица, издвајају се следеће културе: пшеница (gendüm), јечам (şa'ır), раж (çavdar), овас ('alaf, 'alef, yulaf) и просо (erzen), затим кукуруз (misır) и пасуљ (fasulye). Бејтулмал (beyt'ul-mal) представља институцију шеријатског права, која у османском пореском систему подразумева, поједностављено објашњено, власништво султана над целокупном имовином која остане без власника. ${ }^{15}$

Треба имати у виду да је османски порески систем знатно сложенији него што је то овде представљено и да су поједине таксе мењале називе, у складу са локалним приликама. У томе и јесте основна карактеристика османске управе. Први дефтери, настали после освајања одређене територије, у складу са бирократском праксом, настојали су да кодификују затечени правни систем. Зато је веома тешко издвојити општа обележја. Временом је долазило и до измена одређених такси, простом бирократском интервенцијом, иако се може са поузданошћу закључити да је образац новог дефтера најчешће следио постојеће стање из претходног дефтера. Долазило је до измене термина, тако да се често под појмом ресим подразумева и ушур, што је чест случај у историографији. Ове термине османска бирократија је мењала терминима адет (adet, обичај), односно махсул (mahsul, приход). Код појединих пореза чест је случај другачије форме, у зависности од дефтера. Тако се порез на млин прикупља по комаду (bab), по години (fi sene) или по камену, односно жрвњу (hacer). Мерна јединица за ширу (müdd) cpeће се и као пинта (pinte). ${ }^{16}$ Груписање појединих ставки такође је произвољно. Тако се конопља и купус могу наћи заједно и кукуруз и пасуљ, што намеће питање начина узгајања ових култура. Процес фискалне трансформације од средине XVI века значајно је утицао на промене у начину прикупљања пореза, смањујући удео земље, односно спахијскотимарског система. Увођење ванредних пореза, авариза, мора се узети у обзир приликом проучавања транзиционог периода. Само стање испенџе, која није претрпела промене у новчаном еквиваленту у периоду од два века, уз појачану инфлацију током револуције цена и уз обиље других доказа из ахкам дефтера, сведочи у прилог чињеници о ванредним наметима tekalif-i şakka које су спахије наметале становништву мимо дефтером одређених дажбина. Процес чифтличења додатни је у низу механизама оптерећења локалног становништва. Коначно увођењем илтизам система и приватизацијом процеса сакупљања пореза, битно се мењала реалност поданика османског султана. Посткласична дефтерологија, на тај начин, испољава само један део постојећих пореских обавеза локалног становништва који се кретао око $50 \%$ и свакако није могао прелазити $60 \% .{ }^{17} \mathrm{C}$ обзиром на тешкоће у раду са архивском грађом османске провенијенције, које

\footnotetext{
${ }^{15}$ Ziya Kazıcı, Osmanlılarda Vergi Sistemi, İstanbul 1977; Mubahat S. Kütükoğlu, Ekonomski život u osmanskoj državi, u: Historija osmanske države i civilizacije II (Ekmeleddin Ihsanoğlu, priredio), Sarajevo 2008, 21-33.

${ }^{16}$ Neşet Çağatay, Osmanlı Imparatorluğunda Reayadan Alınan Vergi ve Resimler, Ankara Üniversitesi Dil ve Tarih-Çoğrafya Fakültesi Dergisi, Cilt 5, Sayı 5, 1947, 483-511; Said Öztürk, Osmanlı Arşiv Belgelerinde Siyakat Yazısı ve Tarihi Gelişimi, İstanbul 1996, 133-163; Dr. Gyula Kaldy-Nagy, Kanuni Devri Budin Tahrir Defteri (1546-1562.), Ankara 1971, passim.

${ }_{17}$ О процесу фискалне трансформације вид.: Linda T. Darling, Revenue-Raising and Legitimacy. Tax Collection and Finance Administration in the Ottoman Empire 1560-1660, Leiden - New York - Köln 1996.
} 
задаје лингвистички проблем, циљ овог рада је да представи одговарајући превод, транслитерацију и оригинални документ, како би будући рад у области посткласичне дефтерологије приближио истраживачима и указао на структуру османског пореског система и начин њиховог инкорпорирања у дефтере. Осим постојећег обрасца, наведене су могуће варијације, чиме се указује на сложеност пореског система и сугерише правац даљих прочавања дефтера. Приликом транслитерације није бележена дужина вокала. С обзиром на научну несагласност поводом овог питања, примењена је ортографија која је већински заступљена како у турској историографији тако и у османистици уопште.

Осим пореза представљених у самом документу могу се још наћи и следећи порези:

- Порез на млин (asyab), који се води по бројном стању - комаду (bab), односно жрвњу (hacer). Понекад је уписана одредница стари (nim sale). ${ }^{18}$

- Ушур на ливаду (öşr-i çayır), који се води по колима (araba) ${ }^{19}$

- Приход на жир (mahsul-1 bellut) ${ }^{20}$.

Документ:

Село Рушањ, друго име Рушак, код Ресника, припада Београду ${ }^{21}$

Гораћ Стојан Живан Станоје Давид брат му

Милорад Митар Милосав Гордан Витомир Лазар

Приход:

$\begin{array}{lllll}\text { испенџа } & \text { пшеница } & \text { јечам } & \text { раж } & \text { овас } \\ \text { особа } & \text { кејла } & \text { кејла } & \text { кејла } & \text { кејла }\end{array}$

$6 / 150^{22} \quad 56 / 392 \quad 40 / 280 \quad 24 / 168 \quad 8 / 56$

просо ушур од кукуруза и пасуља шира $\quad$ ушур од конопље, купуса и црног лука

кејла $600 \quad$ медри 280

$8 / 56 \quad 600 / 3000$

ушур од кошница порез на свиње и божић пољачина порез на башту, огревно дрво и сено 240 130

320

порез на тапије на земљу $48 \quad 160$

приход од општег бејтулмала, имања одсутних и несталих лица, ухваћене стоке, одбеглог роба и других одбеглих од кућа 1000

ушур на воће: 120

бадихава, свадбарина, порез на винску бурад, казнене и криминалне преступе, порез на одбегле: 400

Укупно: 7.400

\footnotetext{
${ }^{18}$ TKGM. TADB. TTD. No. 18, str. 50.

${ }^{19}$ TKGM. TADB. TTD. No. 18, str. 47.

${ }^{20}$ TKGM. TADB. TTD. No. 18, str. 47.

${ }^{21}$ TKGM. TADB. TTD. No. 18, str. 45.

${ }^{22}$ Сви бројеви су, иако то у дефтеру не пише експлицитно, дати у акчама. Старија историографија користи термин аспра.
} 


\section{Транслитерација:}

Karye-i Ruşan nam diğer Ruşak nezd Resnik tabi' Belgrad

$\begin{array}{llllll}\text { Goraç } & \text { İstoyan } & \text { Jivan } & \text { İstanoye } & \text { David } & \text { birader } \\ \text { Milorad } & \text { Mitar } & \text { Milosav } & \text { Gordan } & \text { Vitomir } & \text { Lazar }\end{array}$

\section{Hasıl}

\begin{tabular}{|c|c|c|c|}
\hline $\begin{array}{l}\text { İspence } \\
\text { neferan }\end{array}$ & $\begin{array}{l}\text { Gendüm } \\
\text { keyl }\end{array}$ & $\begin{array}{l}\text { Şa'ır } \\
\text { keyl }\end{array}$ & $\begin{array}{l}\text { Çavdar } \\
\text { keyl }\end{array}$ \\
\hline $6 / 150$ & $56 / 392$ & $40 / 280$ & $24 / 168$ \\
\hline
\end{tabular}

$\begin{array}{llll}\begin{array}{lll}\text { Erzan } & \text { Öşr-i mısır mea fasulye } & \multicolumn{1}{c}{\text { Şire }} \\ \text { müddre }\end{array} & \begin{array}{c}\text { Öşr-i kendir ve kelem ve piyaz } \\ \text { keyl }\end{array} & 600 & 280 \\ 8 / 56 & & 600 / 3000 & \end{array}$

Öşr-i küvvare Bid'at mea bojik 'Adet-i deştbani Resm-i bostan ve hime ve giyah $\begin{array}{llll}240 & 130 & 48 & 160\end{array}$

Resm-i tapu-ı zemin Mahsul-ı beyt ül-mal-ı 'amm ve mal-ı gayib ve mefkud ve yuva 320 ve kaçkun ve gayri-ez ev-i abık ${ }^{24}$ 1000

$\begin{array}{ll}\begin{array}{l}\text { Öşr-i } \\ \text { meyve }^{25}\end{array} & \begin{array}{l}\text { Bad-ı heva ve resm-i 'arus ve resm-i fuçi ve } \\ \text { cürm-ü cinayet ve resm-i haymanegan }\end{array} \\ 80 & 400\end{array}$

Yekun

5200

\footnotetext{
${ }^{23}$ У TTD 17 ова ставка не садржи piyaz, већ је он исказан као resm-i bostan ve giyah ve piyaz. Порез на огревно дрво (hime) тамо није заступљен.

24 У TTD 17 формулација којом се завршава овај порез је: и других (ve gayrihi).

${ }^{25}$ Овај порез није заступљен у TTD 17.

26 Душанка Бојанић преводи као „скитачка раја“. Могући превод је: номад, мигрант, сиромашан, скитница. James W. Redhouse, A Turkish and English Lexicon, Istanbul 2006, 878; Реч је о раји која је напустила своја имања услед немогућности да редовно сервисира своја пореска оптерећења и која се у литератури најчешће наводи као раја изван дефтера (defter harici re'aya; haric ez defter), као расути (perakende) или села без paje (karye-i hali ez rea'ya). Halil Inalcik, The Ottoman Decline and its Effects upon the Reaya, u: Aspects of the Balkan. Continuity and Change (Eds. H. Birnbaum, S. Vryonis), The Hague - Paris 1976, 350; Р. Тричковић, Катастарски попис Крајине и Кључа из 1741. године, 245.
} 


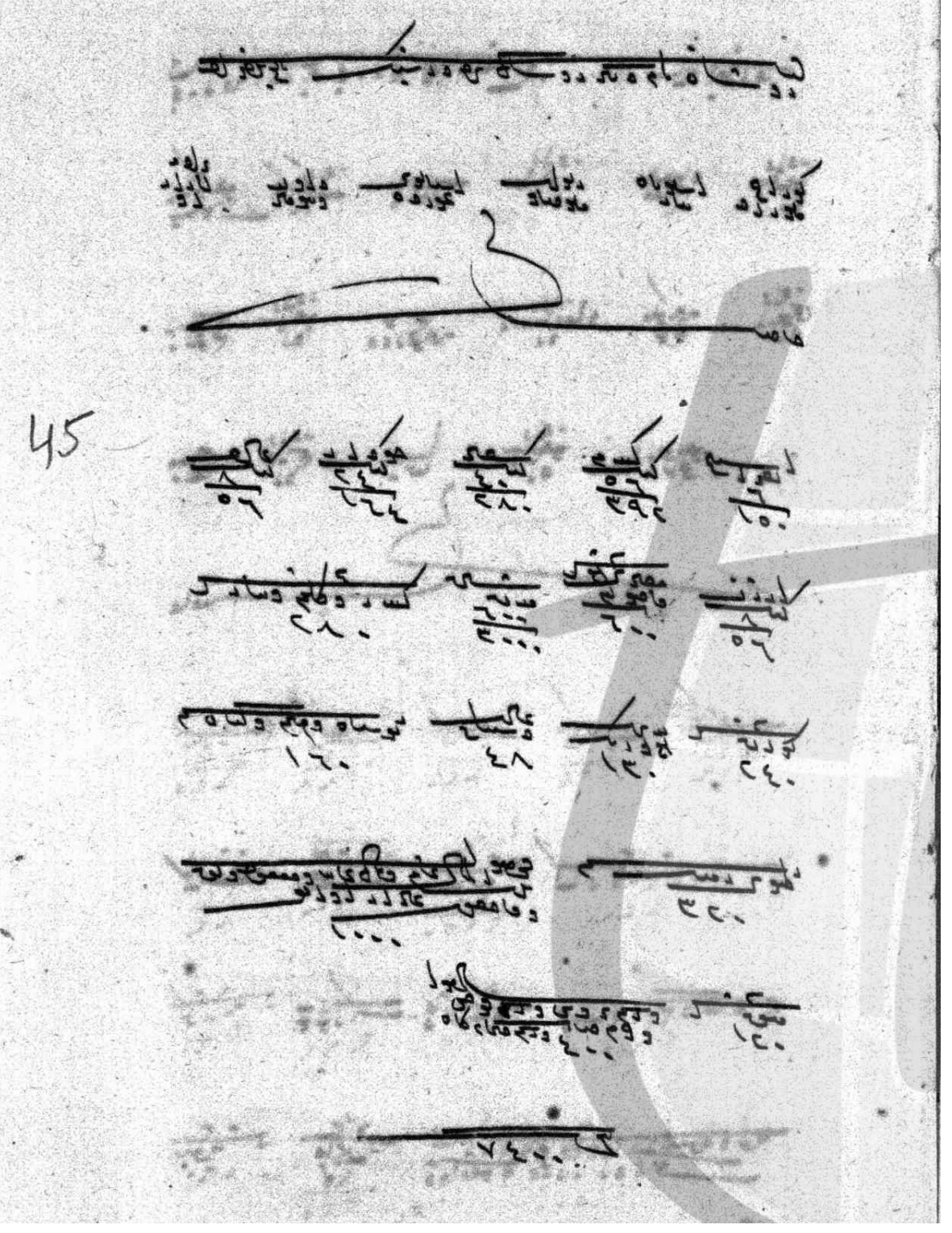




\section{Извори и литература:}

Необјављена архивска грађа:

Tapu ve Kadastro Genel Müdürlüğü, Tapu Arşiv Dairesi Başkanlığı, Tapu Tahrir Defterler (skraćeno: TKGM. TADB. TTD.), No. 0017; No. 0018; No. 166.

\section{Литература:}

Bajraktarević, Fehim, Glavni Carigradski arhiv i ispisi iz njega, Prilozi za orijentalnu filologiju, No. VI-VII, 1958.

Bojanić, Dušanka, Turski zakoni i zakonski spomenici iz XV i XVI veka za Smederevsku, Kruševačku i Vidinsku oblast, Beograd 1974.

Çağatay, Neşet, Osmanlı Imparatorluğunda Reayadan Alınan Vergi ve Resimler, Ankara Üniversitesi Dil ve Tarih-Çoğrafya Fakültesi Dergisi, Cilt 5, Say1 5, 1947.

Čolić, Ljiljana, Orijentalističko delo Gliše Elezovića, Beograd-Priština 1996.

Darling, Linda T., Revenue-Raising and Legitimacy. Tax Collection and Finance Administration in the Ottoman Empire 1560-1660, Leiden - New York - Köln 1996.

Demirci, Süleyman, The Functioning of Ottoman Avariz Taxation: An Aspect of the Relationship Between Centre and Periphery. A Case Study of the Province of Karaman, 1621-1700, Istanbul 2009.

Elezović, Gliša, Iz carigradskih turskih arhiva - Mühimme defteri, Beograd 1951.

Göyünç, Nejat, XVI. Yüzyllda Mardin Sancağl, İstanbul 1969.

Hadžibegić, Hamid, Džizja ili harač, Prilozi za orijentalnu filologiju, No. V, 1954-55.

Inalc1k, Halil, The Ottoman Decline and its Effects upon the Reaya, u: Aspects of the Balkan. Continuity and Change (Eds. H. Birnbaum, S. Vryonis), The Hague - Paris 1976.

Kaldy-Nagy, Dr. Gyula, Kanuni Devri Budin Tahrir Defteri (1546-1562.), Ankara 1971.

Kazıc1, Ziya, Osmanlılarda Vergi Sistemi, İstanbul 1977.

Kiel, M., Remarks on the Administration of the Poll Tax (cizye) in the Ottoman Balkans and Value of the Poll Tax Registers (cizye defterleri) for Demographic Research, Etudes Balkaniques, No. 4, 1990.

Kolovos, Elias, Beyond 'Classical' Ottoman Defterology: A Preliminary Assessment of the Tahrir Registers of 1670/71 Concerning Crete and the Aegean Islands, u: The Ottoman Empire, The Balkans, The Greek Lands: Toward a Social and Economic History. Studies in Honor of John C. Alexander (E. Kolovos, Ph. Kotzageorgis, S. Laiou, M. Sariyyanis, Eds.), Istanbul 2007.

Kütükoğlu, Mubahat S., Ekonomski život u osmanskoj državi, u: Historija osmanske države $i$ civilizacije II (priredio Ekmeleddin Ihsanoğlu), Sarajevo 2008.

Lowry, Jr. Heath, Studies in Defterology. Ottoman Society in the Fifteenth and Sixteenth Centuries, Istanbul 1992.

Özel, Oktay, Osmanlı Demografi Tarihi Açısından Avarız ve Cizye Defteri, u: Osmanlı Devleti'nde Bilgi ve İstatistik (Ed. Halil İnalcık, Şevket Pamuk), Ankara 2001.

Öztürk, Said, Osmanlı Arşiv Belgelerinde Siyakat Yazısı ve Tarihi Gelişimi, İstanbul 1996.

Parveva, Stefka, Villages, Peasants and Landholdings in the Edirne Region in the Second Half of the 17th Century in Regions, Borders, Societies, Identities in Central and Southeast Europe, 
17th - 21th Centuries. Bulgarian-Hungarian History Conference Sofia 16-17 May 2012 (Eds. Penka Peykovska, Gabor Demeter), Sofia-Budapest 2013.

Parveva, Stefka, Agrarian Land and Harvest in South-West Peloponnese in the Early $18^{\text {th }}$ Century, Etudes Balkaniques, 2003, Issue No.1, 2003.

Redhouse, James W., A Turkish and English Lexicon, Istanbul 2006.

Stojaković, Momčilo, Braničevski tefter, Beograd 1987.

Тричковић, Радмила, Катастарски попис Крајине и Кључа из 1741. године, Мешовита грађа, књ. 2, 1973.

Zarinebaf, Fariba, Bennet, John, Davis, Jack, A Historical and Economic Geography of the Ottoman Greece. The Southwestern Morea in the $18^{\text {th }}$ Century, Athens 2005. 


\title{
A DETAILED OTTOMAN LAND REGISTER (DEFTER-I MUFASSAL) FOR THE SANCAK OF SEMENDIRE FROM 1741: A STRUCTURAL ANALYSIS
}

\begin{abstract}
Summary
In 1741 a detailed defter for the Sancak of Semendire was created during the postclassical period, during which the significance of this type of documents in bureaucratic practice was brought to minimum as a result of the process of fiscal transformation. The lifting of tax burden imposed on the landholdings, crisis of the spahiatymar system, privatisation of the mechanism of tax collecting through the 'iltizam' system, all resulted in the transformation of the form of address between the centre and the periphery. As during the transition period (17th-18 ${ }^{\text {th }}$ centuries) defters appeared sporadically and most often after a certain territory had been brought back to the Ottoman rule, modern historiography has introduced the term postclassical defterology. The primary characteristics of these defters are the lesser credibility of data, their dependence on the principles of earlier Ottoman defters, rather than on the principle of the system of governance established there by the foreign management, and the creation of defters on the principles based on the size of the landed property for each particular household (hane). The Semendire Sancak defter of 1741 did not record the area of the landholding, but was obliged to follow a similar principle in relation to the differences in rate of taxation for each settlement in particular. The paper presents the pattern of taxation, points to variations in the two existing defter registers (TTD 17 and TTD 18), and makes reference to the relevant original, provides transliteration and translation.
\end{abstract}

Keywords: Ottoman Empire, Sancak of Semendire, defterology, tapu tahrir defteri, taxation system, öşür, resim. 